\title{
Virumaa kalendritavad ja nende piirkondlik omapära ${ }^{1}$
}

\author{
Mall Hiiemäe
}

Teesid: Rahvakalendri aluseks on ajaarvamine ning sellega seotud uskumuste ja kommete kogum, mis vastavuses looduse rütmidega on välja kasvanud lähtuvalt põhielatusaladest. Tavandis on oluline koht eri tähtpäevade juurde kuuluval ennetaval maagial eriti seoses suuremate töötsüklite (nt lõikusaeg, kalapüügihooaeg) alustamise ja lõpetamisega, aga ka keeldudel ja soovitustel seoses koduste toimetustega. Pikaaegselt välja kujunenud kalendaariumi tähendussisus on koha leidnud nii pereliikmeid kui ka suuremaid kooskondi hõlmavad ühistegevused: ohverdamistoimingud, meelelahutuslikud kooskäimised jne.

Artiklis toon esile Virumaa kalendrikombestiku seoseid põhielatusaladega avalikus ja privaatsfääris ning püüan välja selgitada kultuurisuhteid (soome, vene, vadja-isuri), pidades silmas nende olenevust rahvastiku konfessionaalsest kuuluvusest.Eeldan, et sotsiaalmajanduslikud olud ning kultuurikontaktid on Virumaa regionaalsete erijoonte kujundamisel kõige olulisemad mõjurid.

Märksõnad: elatusalad, funktsioonimuutused, integratsioon, konfessioonikuuluvus, kultuurisuhted, maagia, Virumaa

Vaimse kultuuri osana on rahvakalendri käitumisjuhised oma hoiakutelt konservatiivsed: püüti juhinduda esivanemate põlvest põlve edasi antud tõekspidamistest. Eesti Kirjandusmuuseumi rahvaluulearhiivis hõlmab see aines ajajärku alates 1880. aastatest, informantide mälu arvesse võttes ning trükiste (nt Eesti rahvakalender I-VIII) abil saab võimalikuks vaadata ka kaugemasse minevikku.

Läbi aastasadade on Virumaa läänepoolse osa Pandivere kõrgustiku kultuurmaistu põllumajanduspiirkonna (Kadrina, Rakvere, Väike-Maarja, ka ViruJaagupi khk) 19. sajandi lõpu ja 20. sajandi alguskümnendite töödekalendris kõige olulisemal kohal olnud põlluharimine koos karjakasvatusega. Teisalt on idapoolse osa suured Alutaguse metsamassiivid (Vaivara, Jõhvi, Lüganuse, Iisaku khk) soodustanud väga vanade elatise hankimise viiside - küttimise ja koriluse - kauast püsimist, ning Soome lahe ja Peipsi järve rannikuala elanik- 
konnale on elatist andnud kalapüük. Tänu majandustegevuse mitmekülgsusele on ka rahvakalendri tavand värvikam.

Oma geopoliitilise asukoha poolest on Virumaal ilmseid ühisjooni põliste kultuurikontaktide näol teiste läänemeresoome hõimudega, nt põliste vadjalastega, ning alates peamiselt 16. sajandist siia, eriti Peipsi äärde elama asunud venelastega Iisaku ja Vaivara kihelkonna piires. Soomepoolseid mõjustusi ilmneb põhjarannikul Kadrina, Haljala, Viru-Nigula, Lüganuse ja Vaivara kihelkonna külades. Vaivara kihelkonna kirdeossa ning Narvatagusele asus soomlasi 17. sajandil, lisandus ka vadja ning isuri algupäraga, osalt venestunud asukaid. Muinasskandinaavia maaviljeluskultuuri mõju ulatub Jõhvi kihelkonda, täpsemalt: Pärnu-Narva liinini, hõlmates ka Iisaku ja Vaivara kihelkonna põhjapoolset osa.

Omapäraseid ja unikaalseidki kombestikunüansse on kujunenud erineva usukuuluvuse pinnal. Ristiusk konkretiseeris muistseid aastajaotustähiseid kanoniseeritud pühakutähtpäevadega, ent see protsess oli aeglane. Rudolf Põldmäe (1940: 1) kirjutab: "XVI saj. lõpul oli hooletussejäetud eestlane väga lähedal täielikule võõrdumisele ristiusust. Endiselt austati pühi hiisi, puid, mägesid, kive, allikaid ja ohvriaedu. Kuna katoliku kirik oli teadlikult püüdnud endistesse pühapaikadesse asutada kabeleid, püstitada riste, sambaid, pühakute kujusid jne, et neile üle kanda rahva usulisi sümpaatiaid, siis püsis ka Rootsi ajal katoliiklike mälestusjäänuste austamine. Hulgaliselt käidi koos hävitatud kabelite varemeil, viidi sinna ohvreid ja palvetati. Üheks seesuguseks ohvrikohaks Põhja-Eestis oli näiteks Maarja kabeli vare Viru-Nigula khk.” Protestantliku kiriku organisatsioonide kujunemisega Põhja-Eestis 17. sajandil taandus ka katoliku pühakute kultus. Rahvakalendris püsikohta leidmata olid paljud pühakutähtpäevad rahvaluulekogumise algaegadeks oma tähenduse juba minetanud. Kirikute püüdlused oma mõjuvõimu tugevdada leiavad kajastumist kurtmistes rahva ebausuliste kooskäimiste kohta. Jõhvi pastor on oma 1652. aasta ettekandes võrrelnud rahvakogunemisi Kuremäe Lähtepea kabeli juurde rukkimaarjapäeval, 15. augustil samasuguste ebausuteenistustega Viru-Nigula lähistel Maarja kabeli juures heinamaarjapäeval, 2. juulil. Kreekakatoliku kabelist Kuremäel leidub teateid 1608. aastast, veneõigeusu nunnakloos-ter asutati siia 1892. aastal, suurpühaks taas rukkimaarjapäev (Jumalaema uinumise püha 15. (28.) august, rahvapäraselt bogoroditsa ja kuremäepäev). ${ }^{2}$

Virumaa kaguosas Peipsimaal on segaasustusega külades toimunud ajapikku nii elanikkonna eestistumist kui venestumist (vt Moora 1964: 36-89). Huvitavaid regionaalseid erijooni võib siinses rahvakalendri tavandis täheldada seoses veneõigeusku elanike siirdumisega luteri usku ning üleminekuga vene keelelt eesti keelele. Nn pooleusuliste - poluvernikute e poluvertsikute ${ }^{3}$ kohta 
on O. W. Masing kirjutanud juba 1821. aasta 12. jaanuari Marahva NäddalaLehes (nr 2, lk 11): "Tarto ja Narwa wahhel, sure Peterpurri tee äeres, on Isako kirrik, mis Jõhwi kirriko kabbel on, kuhhu õpetaja kolme nädala taggant jutlust tulleb piddama. Selle weikese kihhelkonna rahwas on muist Poolwernikud, se on makele: poleusso rahwas. Nemmad on kül meie usku, agga käivad wenne ridis; rägiwad kangeste ma-, ja parremaste wenne keelt; kannawad ka ristikessi kaelas, löwad nenda, kuida wennelaesedki, risti enneste ette, ja kui wenne kirrikusse juhtuwad: siis seäl pühhade kujude ette küünlaid pannewad, ja nende ette kummardawad. Sellepärrast, et nemmad nenda kahhe wahhe peäl, neid Poolwernikuks, ehk poleusso rahvaks kutsutakse.” Samasugust ebamäärase halduse ja usukuuluvusega rahvast võib leida ka Tudulinna, Rannapungerja ning Kauksi mail, lisab O. W. Masing.

Virumaa talupojakultuuri esindavas rahvakalendris kuuluvad 19. sajandi lõpu- ja 20. sajandi alguskümnenditel Eesti Rahvaluule Arhiivi andmete järgi kõige olulisemate tähtpäevade hulka tõnisepäev (17. jaanuar), küünlapäev (2. veebruar), vastlapäev, paastumaarjapäev (25. märts), lihavõtted, jüripäev (23. aprill), jaanipäev (24. juuni), mihklipäev (29. september), mardipäev (10. november), kadripäev (25. november) ning aastavahetus jõulupühade (25.-27. detsember), uusaasta (1. jaanuar) ja kolmekuningapäevaga (6. jaanuar). Regionaalsete, enamasti vastastikuste kultuurimõjustuste tulemusel kujunenud erijoonte poolest väärib esiletoomist kolmekuningapäeva, paastu-, heina- ja rukkimaarjapäeva, jüripäeva, hingedeaja, kadripäeva ning tabanipäeva (26. detsember) ${ }^{4}$ kombestik.

Vene õigeusu kirik tähistab pühi vana (Juliuse) kalendri järgi ega tunnista üleminekut uuele (Gregoriuse) kalendrile. Ka on mitmed eesti rahvakalendris populaarsed tähtpäevad, nagu tõnisepäev, mihklipäev, mardipäev ja kadripäev, õigeusule orienteeritud kogukonnale võõrad või vähetuntud. Venepärane on külapühade pidamine kiriku- või kabelipühaku mälestuspäeval suguvõsa kooskäimise, vastastikuste kostitamiste ja meelelahutusega, mis kestavad enam kui ühe päeva. Nt Remnikus on külapühaks jüripäev (23. aprill / 6. mai), Agusalus kevadine nigulapäev (9./22. mai), Vasknarvas ning Skamja k teispool Narva jõge eelijapäev e ilja (20. juuli / 2. august), Smolnitsa k makavei (1./14. august) ${ }^{5}$, Kuremäel uspensk (15./28. august), Alajõel bogoroditsa (Neitsi Maarja sünnipüha, 8./21. september), Uuskülas pokrov (1./14. oktoober) $)^{6}$, Karoli ja Kuru k midrusk (26. oktoober) ${ }^{7}$, Katasel kaasani maarjapäev e kasansk (22. oktoober / 4. november $)^{8}$, Jaama k talvine nigulapäev (6./19. detsember), Karjamaa e Võgana k Kristuse sünnipüha (25. detsember / 7. jaanuar). Õigeusu kiriku seos elatusaladega on üldse tugevam kui see on evangeelse luteriusu kiriku sätetes.

Järgnevas keskendun olulisematele kalendritavandi teemavaldkondadele ning toon esile Virumaa kohalikke eriarenguid. 


\section{Aastajaotustähised}

Aasta liigendamise süsteemidest on esile tuua enam kui üks. Päikesekalendris on silmaganähtavaks orientiiriks päikese asend taevavõlvil: kõige kõrgema päikeseseisu tähiseks sai jaanipäev, kõige madalamat seisu märgivad jõulud. Maaviljelus sai põhimiseks elatusalaks I aastatuhandel m.a.j, siitpeale võime arvestada majandusaasta jaotusega aktiivseks ehk suvepooleks ja passiivseks ehk talvepooleks. Üleminekukohta märgivad vastavalt jüripäev ja mihklipäev, mõlemaid on juurutanud baltisaksa mõisnikud seoses töölepingute sõlmimisega talurahva seas. Aasta suvepool on niisiis pikem kui talvepool: Rahvas loeb praegu töö tarvis aega isemoodi - suvi 23 nädalat, talv 29 nädalat. Suvi jüripäävast mihklipäävani (Haljala, 1917). Pööripäevad jagavad tsiviilkalendri aasta neljaks veerandiks, ent rahvakalendris pakuvad veerandaasta tähistena neile tugevat konkurentsi paastumaarjapäev, jaanipäev, mihklipäev ja jõulud. Seoses 1. jaanuari kehtestamisega aasta alguse päevaks 1691. aastal kujunesid eeldused ennetava maagiaga seotud jõulukombestiku kandumiseks vana-aasta õhtule.

Aastajaotuses leidub jälgi veel koguni ristiusueelsest ajast, aluseks talve keskpaika märkiv talihari (14. jaanuar), põllutööde alguse tähis künnipäev (14. aprill), taliharja suvepoolne vastasdaatum ja rukkikesa künni tähis karusepäev (13. juuli), ning taimevegetatsiooni lõppemist märkiv kolletuspäev (14. oktoober). Taliharja tähendus kandus Põhja-Eestis tõnisepäevale: Tõnisepäev on talve harja päev (Simuna); Tõnis murrab talve seljaluu katki, see on: pool talve on siis mööda (Vaivara). Virumaal on sellesisuliste vanasõnade kirjapanekuid rohkem lääne- kui idapoolsetest kihelkondadest pärit rahvaluulekorjandustes, Lõuna-Eestis on talve poolitajaks küünlapäev. Künnipäevaga seonduvad traditsioonid kandusid rahvaluulekogumise algusaegadel jüripäevale, karusepäeva pole Virumaal nähtavasti tuntudki ning kolletuspäeva tundmine on pigem oletuslik.

Sügisese lehelangusega algav üleminek talvele toob endaga hingedeaja mõiste, kuid Virumaal see aastajaotusega ei seostu. Küll aga on kalendrilise määratluse saanud põhjarannikul Kadrina, Haljala, Viru-Nigula ja ka Lüganuse khk ajalõik "üheksa päeva enne marti”, mis kannab jaguaja nimetust. Jägu ajad on 9 pääva enne mardipääva, 1. novembrist 9. novembrini. Sel ajal on Aljalas alati vagane, mitte tuule lehku. Vali sügisene loodetuul akab pärast jägu aega idapõhjast puhuma (Haljala, 1917). Kujutlus jaguajast on ühine soomlastega, oluliseks on peetud ilmavaatlust eelolevaks talveks ja Kadrina khk Eru k isegi suveks. Mida rohkem ida poole, seda enam on teadmised jaguajast tuhmunud, nt Viru-Nigula khk Lahe k: Jäguaeg oli ilmade muudu aeg, sügisepoole ikka oli (1930). Lüganuse khk Rõusa k anti jaguaja kohta seletus, et untidele anneti 
siis üks kord aastas jagu, ülevelt anneti (1931). Tegelikult võib jaguaja mõiste olla välja kasvanud kuukalendri ja päikesekalendri ühitamise vajadusest.

\section{Nädal ja nädalapäevad}

Nii nagu kuude (lunatsioonide) arvestus, lähtub ka nädalate arvestus kuukalendrist. Aastaring või osa sellest loendati kalendripühade kaupa, öeldes, mitu nädalat nende vahele jääb:

Vanal eestlastel, kui veel tähtraamatud puudusid, lugesid aega nädalate kaupa päheõpitud kalendri näol. Meie pool oli pidepunktiks kü̈̈nlapäev. Kü̈̈nlapäevast loeti seitse maarjapäeva, 25. märts, maarjapäevast neli jüripäeva, 23. apr., jüripäevast üheksa jaanipäeva, 24. juuni, jaanipäevast seitse lauritsapäeva, 10. aug., lauritsapäevast seitse mihklipäeva, 29. sept., mihklipäevast kuus marti, 10. nov. mardipäevast kaks kadripäeva, 25. nov., kadripäevast neli jõulu, 24. dets., jõulust kuus küünlapäeva. Ja oligi ring täis aasta 52 nädalat. (Haljala khk, Läsna k, 1982)

Lugunädalate variante on palju, loend võib alata nt mihklipäevast, ning just küünlapäevast alustatavates loendites võidakse kasutada tagurpidijärjestust ning kujundlikke tunnussõnu:

Nii oli kü̈̈nlapäevast nädalaid: “Kümme kündi, üksteist jürgi, üheksa härjaörina, kaheksa karjalasku, seitse siusse ja kolm kukevõtme.”-Kolme nädala pärast, s.o madisepäeval pidi siis kukk juba võtme kätte saama, nii et ta võis väljas käia. Temale järgnesid seitsme nädala pärast sead ja kaheksa nädala pärast kariloomad. (Rakvere khk, Mõdriku k, 1970)

Tava lapse sündimise nädalapäeva järgi tema tulevikku ette arvata ei tuleks tõsiselt võtta. Nimelt määrab siin sõnavaliku algriim. Väike-Maarja khk Porkunist kirja pandud tekstis ennustati: Kes esmaspäeval on sündinud, see on edev, teisipäeval - tegev, kolmapäeval - kade, neljapäeval - ninakas, reedel - rikas, pühapäeval - püüdlik (1935). Samahästi võib kesknädalal sündinust saada kena, neljapäeval sündinust nobe või näljane, reedel - riiakas, laupäeval laisk inimene.

Märksa asjalikum on nädala toidukordade arvestus: Vanasti on olnud kindlad söögid igal päeval. Esmaspäeval kartulisupp, teisipäeval hernesupp, kolmapäeval tangupuder, neljapäeval kapsasupp, reedel kiisel, laupäeval kartulipudru, pühapäeval kapsasupp (Simuna, 1939). Toitude järjekorrast peeti rohkem kinni talvel. Kolmapäev ja laupäev olid kindlalt pudrupäevad ning neljapäev ja pühapäev lihaga keedetud kapsasupi päevad. 
Ühtlustatud tsiviilkalendris kuufaasid enam nädalapäevadega seotud ei ole, kuid osa väga vanu kuukalendrist lähtunud usundilisi kujutelmi näib olevat tänini püsinud. Nädalapäevade seas on esmaspäeva peetud tööde alustamiseks sobimatuks. Simuna khk Paasverest on kirja pandud kinnitus, et isegi parun Schilling sellest käitumisjuhisest kinni pidas. Hoiduda tuli uude kohta kolimisest, reisileminekust, laevaga merele sõitmisest, kaubalepete sõlmimisest, ka ei tohtinud esmaspäeval raha käest ära anda. Nädala alguspäeva peeti teiste nädalapäevadega võrreldes õnnetuks päevaks.

Nädala teist päeva on soositud kui paarisarvulist päeva. Tööde alustamiseks on teisipäev sobiv. Öeldi, et kui paarispäeval herneid külvata, kasvavad paaris kaunad, Ranna-Virumaal eelistati kalale minna nimelt paarispäevadel. Kolmapäev nii hea mainega pole, seda on veel 19. sajandil loetud halvaks päevaks.

Neljapäev on olnud vägagi oluline, selle pühitsemist peeti kaua aega tähtsamaks kui pühapäeva pühitsemist. Üldine oli koduste tubaste tööde keeld, selle asemel aeti juttu, mindi ka teistesse peredesse aega veetma. Iisaku khk eestistunud külades käisid tüdrukud suprekal (vn супрядки) - ühistel käsitööõhtutel. Ka kodudes oli teenijatüdrukutel luba enda tarbeks käsitööd teha. Kadrina, Rakvere ja Jõhvi teadetes on neljapäeva nimetatud kosjaskäimise päevaks. See päev sobis maagilisteks toiminguteks, nt varandusevedaja (pisuhänna e tondi) tegemiseks. Kadrina kihelkonnas on mainitud ka ohverdamist hiies. Veel 1984. aastal viis Viru-Jaagupi khk 82aastane naine neljapäeva seosesse kuufaasiga: Saunavihad tuleb teha jaanieelsel vanakuu neljapäeval, muidu hakkab nahk sügelema, kui viheldi.

Reede on õnnetu päeva maine poolest kõrvutatav esmaspäevaga, ka keelud on samad. Puhuti on oluliseks peetud kuufaasi, nimelt kas vana või noore kuu reedet (teateid on Haljala, Rakvere ja Jõhvi khk).

Laupäeva on üksmeelselt peetud kõige sobivamaks aeganõudvate tööde alustamise päevaks. Usuti, et töö läheb siis ladusalt ning jõuab kiiresti lõpule. Rakvere khk ja Narva pärimusteadete järgi pidi laupäevane vihmasadu pühapäeval jätkuma. Laupäeva öösel vastu pühapäeva nähtud unenägu pidi täide minema (Kadrina, Väike-Maarja, Rakvere khk). Kui jüripäev 20. sajandil oma sotsiaalse tähenduse minetas, hakati karja välja laskma seda enam laupäeval kui kõige õnnekamal päeval.

Sellest kombest me pidasime veel kolhoosis kinni ja ikka lasksime tingimata laupäeval loomad välja. Sie pidi hea päev olema. Meil oli vahepeal selline ülemus, ajas peale, et pühapäeval karja välja saata. Üks lüpsja ütles talle kohe, et küll sa näed, õnnetus tuleb. - Oh, mis seal tulla saab! See on vana ebausk! - Ja üks lehm ometi hüppas üle aia ja murdis jala. (Viru-Jaagupi, 1984) 
Pühapäeva pühitsemine kujunes reegliks alles 19. sajandil kiriku abiga. Lüganuse khk on pühapäevase töötegemise karistusest mitmeid hoiatusjutte:

Pühäpäivä pühütsetakse Lügänüse kihelkonnas ualega. Kes pühäpäiv tüöd julgeb tehä, sedä saab Jumal ise nuhtlema. Ka kõige kiiremal eina aal ei tõhi keägi einäle mennä, sest nie einäköksi, midä pühäpäiv kokku pannase, muudab Jumal kivis. (1888)

Nii pühakupäevade töökeelde, pühapäeva pühitsemise nõuet kui uskumusi nädalapäevade erineva kvaliteedi kohta on Peipsi põhjaranniku vene külades tõsisemalt võetud kui Virumaal keskmiselt.

Näide ööpäeva rahvapärase liigenduse kohta ajast enne kella kasutuseletulekut on pärit Haljala khk:

1. Südaöökoht. 2. Pääle keskööd (“kolm koitu enne sea sõitu”). 3. Koidu otsas, koit väljas. 4. Pääva tõusu ajal. 5. Vara ommiku. 6. Enne keskommikut. 7. Keskommiku. 8. Pääle keskommikut. 9. Pääv "noores lõunas”. 10. Lõuna eel. 11. Lõuna ajal. 13. Pääle lõunat, keskõhta eel. 14. Keskõhta ajal. 15. Pääle keskõhtat, pääva veeru eeli. 16. Pääva veeru ajal. 17. Ehavalge otsas. 18. Enne keskööd. (1917)

\section{Looduse- ja ilmavaatlus}

Tähtpäevade juurde kuuluva loodusevaatlusega saadud pikaaegne kogemus on vormunud rahvatarkuseks, mida kujundkõnes, enamasti vanasõnade kujul põlvest põlve kasutatakse. Aastaajaliste muutuste toimumist tähele pannes hinnatakse neid kalendritähtpäevade toel varaseks või hiliseks, vastavalt tehakse otsustusi tööjärje, vilja- ning karjakasvu ja edaspidiste ilmade kohta.

Päevade pikenemist märgib ütlus: kolmekuningapäevast peale on päev juba kukesammu võrra pikem. Iisaku kihelkonnast kirja pandud vanasõnas on tärminiks ka tõnisepäev: siitpeale on päev ahjukütmise jagu pikem. Talvekeskme tähisena on tõnisepäev Virumaal üldse hästi tuntud (algab teine pool talve ja karu keerab koopas teise külje). Talvekeskmena jääb küünlapäev tõnisepäeva varju. Küünlapäev on rohkem kevademärkide kandja. Lüganuse kihelkonnas on öeldud, et siitpeale hakkab hunt uluma (käes on jooksuaeg), Haljala ja Simuna kihelkonna teadetes paneb vares küünlapäeval esimese pesapalgi, Vaivara, Viru-Jaagupi ja Väike-Maarja teadetes hakkab kõrs juba lund vihkama. Kuigi madisepäev (24. veebruar) on Virumaa rahvatraditsioonis üsna vähepopulaarne, kuulub Kadrina ja Viru-Nigula rannarahvale ütlusi kevadtalve merejää kohta: madis jääd teeb või lahutab (ka: rikub või rakendab); kui madisepäeval lund sajab, on pool lund veel taevas (Eru k). 
Paastumaarjapäevast on arvestatud keskmiste temperatuuride jõudmist $0^{\circ}$ piirile. Siia kuulub rohkesti tähelepanekuid kevade saabumise kohta: karu tuleb talvepesast välja, ronk ristib lapsi, vares paneb esimese pesapalgi (või muneb esimese muna), on sookure saabumise aeg, haug hakkab ülesvett ujuma, madu näitab ennast. Ilmaprognoos lähemateks nädalateks on järgmine: kui maarjapäeval on lumi katusel, siis jüripäeval on hanged aia ääres; kui külm lööb maarjapäeva öösel kanamuna aiaposti otsas katki, siis tuleb veel 40 öödpäeva külma aega.

Päikese mängu vaatamise traditsioonist lihavõttehommikul on enam teateid Põhja- kui Lõuna-Eestist. Vaatluste kohta leidub rahvaluulearhiivis üsna palju kirjapanekuid: päike on rõõmus, liigub üles ja alla, lööb mitmekarvaliseks, käib ruttu ringi (kõik teated on Vaivara kihelkonnast ja Narvataguselt), käib ümber kui ratas (Lüganuse), hüppab edasi-tagasi (Simuna), kiigub (Väike-Maarja), tantsib (Kadrina). Isiklike vaatluste kestuseks on märgitud 3 minutit kuni tund. 20. sajandil leidis komme kasutust kasvatuslikul eesmärgil: öeldi, et päikese mängu saavad näha ainult head lapsed. Vene külades on rahvusvaheline uskumus päikese mängimisest seotud jaanipäevaga, päike mitte ei mängi ega tantsi, vaid supleb (vt ka Truusmann 1895: 15 (10)).

Taimekasvu algust näitav jüripäev on muutuste tähisena tulevikuennete poolest veelgi olulisem kui paastumaarjapäev. Suur osa tõekspidamistest peab silmas aega enne ja pärast jüripäeva, kuid need on sageli vastuolulised. Nii võib äike enne jüripäeva olla külma kevade, halva suve, hea või halva viljasaagi (Lüganuse khk kalasaagi) endeks. Pääsukeste saabumine enne jüripäeva tähendab Iisaku teate järgi varast kevadet, Väike-Maarja teate järgi aga külma, käo saabumine enne jüripäeva tähendab Jõhvi kihelkonnas külma kevadet, Viru-Nigulas sooja sügist, Rakvere kihelkonnas halba saagiaastat.

Kevadiste liikuvate pühade hulgas on ristipäev ehk taevaminemispüha erilise tähendusega. Võib arvata, et tegemist on ristiusueelse pühaga, mis sätestas kõigesse maast kasvavasse puutumise keelu. Kõige ehedamaid teateid sellise püha kohta on vadjalastelt, Viru- ja Võrumaa eestlastelt ja ka soomlastelt. Virumaal teati veel 20. sajandi teisel poolel, et sel päeval ei tohi lille ega oksa murda, rohigi ei kasva, Kurtna ümbruses (Jõhvi khk) öeldi see olevat nii suur püha, et Rakvere raibegi ei kasva (1985). ${ }^{9}$ Uskumuste leviku dominantala on Lääne-Virumaa. Kadrina, Haljala, Väike-Maarja, Rakvere kihelkonnas on märgitud taimekasvu muutust: ristipäevast läheb sool rohusse; idapoolses osas, Jõhvi, Iisaku, Lüganuse, Viru-Nigula, ka Väike-Maarja kihelkonnas on enam tähelepanu pööratud praktilisele poolele: siitpeale pannakse heinamaad kinni. Üle poolte Põhja-Eesti päritoluga kirjapanekutest on Virumaalt. Haruldane teade mitme järjestikuse risti(nelja)päeva teadmisest pärineb Simuna kihelkonnast, need on tuule-, lehe-, linnu- ja suur ehk harilik ristipäev. 
Jaanipäev kui suveaja kõige suurem püha on, nagu jüripäevgi, uskumustes looduse fenoloogilise arengu näitaja. Öeldi, et kui enne jaani ühe parmu maha lööd, tuleb veel üheksa asemele, aga kui pärast jaani parmu maha lööd, kaob üheksa vähemaks. Looduse imejõu andjaks peeti öist jaanikastest, mida tuli koguda silmarohuks ja iluraviks (Haljala, Väike-Maarja, Viru-Jaagupi, Simuna khk). Tulevase kaasa ennustamisest lillepärja viskamisega vette, lille torkamisega seinaprakku, ravimtaimede korjamisest on enam teateid Iisaku ja Vaivara kihelkonnast ning Narvataguselt. Kui kägu kukkus kaua pärast jaanipäeva, isegi heinamaarjapäevani, pidi tulema pikk ja soe sügis.

Eesti rahvapärimuses on eelijapäev üsna tundmatu, seevastu vene külades on Ilja-prohvet kardetud äikesetegija. Jakobipäev, 25. juuli on eestlaste seas laiemalt tuntud suvepoolitaja: vesi jaheneb - külm kivi visatakse vette; rohi puitub - raudnael on rohus; kaste ei kao kannu äärest. Kui peale jaagupipäeva üks tilk sajab, tuleb maast üheksa juurde (Haljala, 1936). Maasikate söömise keelust põhjendusega, et sööja jääb uniseks, on pooled kirjapanekud Virumaalt (Simuna, Viru-Jaagupi, Iisaku), neid marju on nimetatud unimaasikateks. Leidub ka teine põhiliselt Virumaa levikuga uskumus, et pärtlipäevaga (25. august) käib kaasas pärtliraju. Teateid on kuuest Virumaa kihelkonnast, mujalt Eestist vaid Kuusalu khk ja veel Saaremaalt. Vene-õigeusu kalender jakobipäeva ega pärtlipäeva ei tunne.

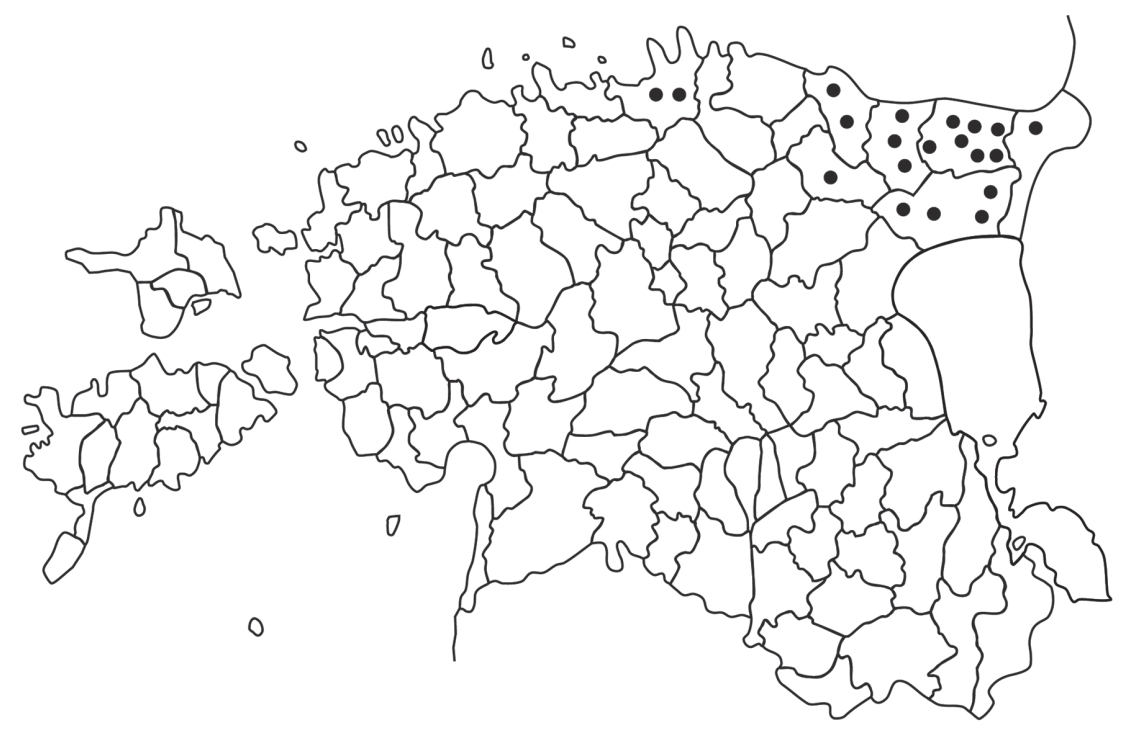

Joonis 1. Teated pärtliraju kohta. 
Sügise saabumise esimesi märke on madude maassepugemine. Sobivat nimetust ussimaarjapäev kannab Neitsi Maarja sünnipüha, 8. september. Enam-vähem samasugused uskumused on venelastel seotud vissenjapäevaga (14./27. september). ${ }^{10}$ Sellal on maod liikvel ja lausa ründavad, seepärast ei tohi metsa marjule minna. Sügisesel madisepäeval (21. september) oli alati merel tormi oodata (Kadrina khk, Läsna k). Mereäärsetes külades jälgiti hoolega tuule suunda nii mihklipäeval kui ka jaguajal: kui meri oli tormine, arvati, et kogu sügis tuleb tormine; kustpoolt tuul neil tähenduslikkudel päevadel puhus, sealt usuti seda puhuvat talve alguseni või koguni kevadeni. Ilmaolude vahelduvust ja talve järkjärgulist tulekut jälgiti tähtpäevade järgi: Enne talist pühi on vanarahva ilmakuulutamine järgmine: "Märt määtäp, kadri kusep, simun tiep silda, niklus niedip kinni, toomas tore mies sõidap.” (Narva-Kreenholm, 1893) Kõige pikemaks ööks pole peetud mitte pööripäeva ööd, vaid luutsipäeva (13. detsember) ööd: siis kukub kotkaski (või ronk) puu otsast alla, jaksamata nii pikalt magada.

Vene vanasõnas Jüri külmetab, Mikol naelutab on talvetoojaks jüripäev (26. november / 9. detsember) ja nigulapäev (6./19. detsember), eesti vaste on nigulas needib, toomas tõukab takka. Jõulud ja uusaasta on aastajaotustähistena kohased pikaaegseks prognoosiks paljudel Euroopa rahvastel. Kui on ilus ilm, tuleb hea suvi, pilves ja udune aeg kuulutab tõbesid, härmatis head teraviljasaaki. Uskumus, et tähine taevas kuulutab ette rohket noorkarja sündi, on venelastel populaarsem kui eestlastel.

\section{Põllundus}

Kolmekuningapäeva juurde kuulub idaslaavi komme pakkuda külmahaldjale kutjaad, et külm suvel vilja ära ei rikuks. Külmataadi kostitamisest on teateid Iisaku kihelkonna Uhe, Soompea, Tammetaguse, Liiva, Vaikla, Smolnitsa, Nurme ja Kauksi külast. Mitut liiki viljast - hernestest, ubadest, odratangudest ja kartulist keedetud putru pandi õue aiaposti otsa sõnadega: Külm, külm, söö nüüd herneid, aga mitte suvel (Truusmann 1895: 14 (4), Tampere 1965: 222-224). Külmale on selliselt toitu pandud ka muudel tähtpäevadel, nt Uhe ja Kauksi k puistati igat seltsi vilja õuele vana-aasta ööl ja Soonpea k küünlapäeval. Mujalt Eestist sellise ohverdamiskombe kohta teateid ei ole.

Kuigi madisepäev kevadekuulutajana Virumaal oluliste hulka ei kuulu, on sellel päeval tuule suunda jälgitud, et teha õigeid otsustusi kevadiste külviaegade valikus. Kui tuul puhus samast kandist, kust madisepäevalgi, ei sobinud hernest külvata; mõnel pool hoiduti madisepäeva tuulega ka teravilja külvamast. Et kasvaks pikk lina, sõideti vastlapäeval hobusega külla. 
Et jüripäeval, suvepoolaasta alguse päeval oleks tingimata tulnud põllutööga alustada, selle kohta teated puuduvad, kuid taimelavas põletati prahti. See töö võeti ette jüripäeva hommikul:

Igalt poolt suits tõusis, siis oli taimelaba kütistamine. Puud pandi kraavimuodi kaevatud õõne peale põiki ja õled peale ja siis lepa-aud kubudega (lahti tehtud ja õled peal). Siis muld veel peale. Sääl ta siis audus ja põles. Järgmine ommik aeti laiali, põletati järgi jäend pulgad. Pärast aeti laiali, tipiti kapsa-ja kaalikasiemned piale. Taimed olid ilusad. (Kadrina khk, Ojaveski k, 1969)

Iisaku khk Sälliku k olevat enne kuuma tuha sees muna küpsetatud ja siis kapsaseemned sooja lavasse külvatud (1959).

Veel 1970. aastatel osati Virumaa läänepoolses osas arvestada kohaseid külviaegu külvinädalate järgi. Nädalaid loendati enamasti jüripäeva nädalast kahanevas järjestuses kokku kümme. Kõige enne külvati kaer ja oder. Kaunvilja külviks oli volbripäev (1. mai) kõige kohasem. Seejärel võeti ette suvinisu ja linaseemne külv ning kartulipanek. Loodusemärkidest on kõige enam jälgitud toominga õitsemist. Kuuendat külvinädalat peeti rohunädalaks, sellal tuli külvitööst hoiduda, et põld ei rohtuks.

Sootuks teistsugused külviorientiirid on veneõigeusu kalendri järgijatel. Venelaste tavandis ei ole külvinädalaid ega volbripäeva, jüripäev aga on pühendatud karja õnnistamisele ning esmakordse väljalaskmise askeldustele. Põldude kaitsjaks ning saagiõnne andjaks on Mikol. Kevadine nigulapäev on konkurentsitult tähtis põllutööde alustamise päev, sobivaks on peetud ka aega kolmel päeval enne või pärast seda. Kui ilm oli halb, oli karta kehva saaki.

Nelipühadeks püüti külvitööd ära teha. Jaanipäevaks pidi olema sõnnik põllule veetud, rukkikesa küntud, kartul mullatud. Siitpeale algas heinaaeg, mis kestis jakobipäevani. Kuid rukis kui talivili oli erilise tähelepanu all juba varakevadest. Õhtune tulevalges töötamine tuli paastumaarjapäevast lõpetada, hoiatati, et muidu tuli paistab orasele ja kasvab vilets rukis. Jüripäevaks pidi rukkioras juba varese ära katma: märk sellest, et vili on kasvujõus. Maagilisest viljatulu saamisest jaaniööl on teateid Virumaa idapoolsest osast - Vaivara, Iisaku ja ka Viru-Nigula kihelkonnast, tegemist näib olevat vene rahvausundis populaarse ettevõtmisega. Nimelt võttis peremees jaaniööl ette käigu võõrale rukkipõllule ning noppis sealt viljapäid põue, et vilja tulu niimoodi endale saada. Kasuks pidi olema ka rukkikõrte kokkupõimimine. Seda, et Venemaal niimoodi tehakse, meenutati Remniku külas veel 1975. aastal. Järgmine tekst Lemmaku, Kuru, Sälliku ja Porskovo (Vaikla k) poluvernikute kohta on Jakob Hurda rahvaluulekogusse saadetud 1889. aastal: 
Jaaniba lauba üese vastu jaanipääva õhtast üed läks sie, kes omale palju vilja tahi saada, valges riides teise peremehe rukkipõllu piale, leikas sial ühe pihutäie siit, teise sialt, ja nõnna mitmest kõhast, jättis aga nied rukkid sinnasama maha, ja kes õige ahne õli, sie leikas mitme mehe põllu pialt. Sie pidi siis tämale mõeduma ja teise mehe vili täma aita tulema.

Pärast jakobipäeva koondus põllumehe tähelepanu jälle rukkile. Kesakünd pidi tehtud olema, seemne saamiseks tuli rukkirehi üles panna (Väike-Maarja, Viru-Jaagupi, Simuna). Teiseks tärminiks, lauritsapäevaks (10. august) pidi seemnerehi üleval olema (Viru-Nigula, Rakvere), ka pool rukkimaad ette valmistatud (Jõhvi). Külviorientiirid on lauritsapäev, rukkimaarjapäev ja pärtlipäev olenevalt sellest, kas külv tehti vana või uue seemnega.

Põllutööde lõpu päevaks loeti mihklipäeva. Keelust kapsaid mihklipäeva nädalal koristada ja ka hapnema panna (läheb kibedaks, ei kee pehmeks) on teade Kadrina khk. Lõikustänupühal sügiseandide kirikusse õnnistada viimisest on teateid Virumaa läänepoolsest osast, kuid märksa vähem, kui pikkade käsitsi pekstud rukkiõlgede rehetuppa toomise kombest jõuluajaks. Järgmise aasta viljaõnne ennustati kõrte lakkeviskamisega:

Jõulu ja uue aasta laupa õhtu kantud palju õlgi tuppa ja võetud kubust pihutäis õlgi ja visetud nõnda õtsekõhe ülespoole, et õlede tähed üles vastu lage käisid. Kui nüüd palju õlgi lae külge rippuma jäid tähtede pidi, siis ôli head rukkilõikust loota. (Jõhvi khk, Päite k, 1889)

Iisaku ja Vaivara khk lõunaosa eestistunud külades see komme kodunenud pole.

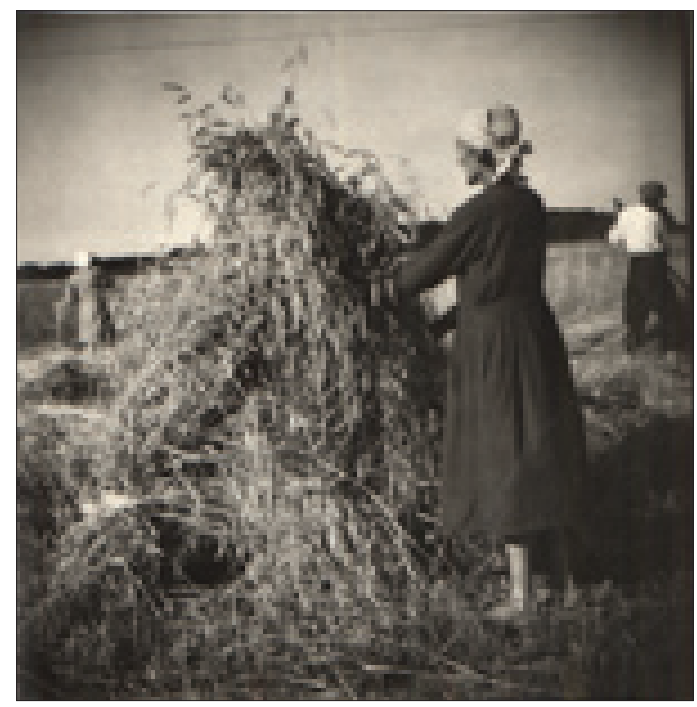

Foto 1. Rukkilõikus lauritsapäeval Jõhvi khk Kohtla k. Foto Endel Mets 1949. ERA, Foto 2267. 


\section{Karjakasvatus}

Talvepoolaastal jagus karjale enam tähelepanu kui lume all puhkavale põllule. Loomatoiduvarude ülevaatamise tärminina oli Virumaal küll tõnisepäev esmatähtis, kuid küünlapäeval tuli ette võtta iseäralik toiming, mida nimetati härja sarvede kõrvetamiseks. See on olnud üsna piirkondlik tava, teateid on nimelt Iisaku ja ka Jõhvi ning Lüganuse kihelkonnast, üksikuid veel Laiuse, Maarja-Magdaleena ja Viljandi kihelkonnast. Noortel härgadel kõrvetati sarvede ümbert karvu, et need ei jääks ikke alla tüliks, et sarved kasvaksid tugevaks ning et noorloomadest sirguksid prisked, tugevad töötegijad. Kuna künniloomadeks on härgi kasutatud juba vähemalt 17. sajandist ja vadja, isuri ega vene traditsioonist analoogiaid teada pole, on H. Tampere (1965: 233) sarvede kõrvetamist pidanud eesti algupäraga kombeks. Ometi kerkib küsimus, miks on teadete põhimiseks päritolukohaks ida poolt sisserännanud rahvastiku asualad - Kauksi, Sälliku, Kaidma, Edivere, Tammetaguse k.

Rahvakalendris võib üks ja sama uskumus seostuda eri tähtpäevadega. Nii saab kanadele võtme andmise tähiseks olla peale madisepäeva ka tõnisepäev (Kadrina, Lüganuse) või vastlapäev (Narva, Simuna). Seajalakontide viimine lakapeale pidi küll toimuma vastlapäeval, et oleks hea põrsaõnn (Kadrina, Väike-Maarja, Rakvere). Iisaku khk Raudi külast pärit soovituse järgi tuli tuhkapäeval laudas ämblikuvõrke maha pühkida, et suvel poleks kärbseid. Järgmised õpetused on kirja pandud Vaivara khk Puhkova k vanalt karjaselt:

Suur reede ehk neljapäe homikul saivad karjatsekepid metsast toodud. Kepp pidi olema üks üksi kasvav pihlakas ja teda pidi ühe nappega maha lööma. Sui otsa pidi karjane sedasama keppi pruukima ja sügisel ta pistis teda katukse räästa. (1888)

Kõige olulisem oli karjase roll seoses karja esmakordse väljalaskmisega:

Jüripäev käib karjane rajade peal hunti kinni panemas, mille tarvis ta kolm nõela nööriga kuuse otsa siub, igale nöörile kolm sõlme. Mihklipäev käib nõelu ära toomas, siis võib hunt jälle kahju teha (Iisaku khk, Oonurme v, 1889).

Hundi jälgede pööramisega - kodu poolt metsa - tegelesid sel tähtsal päeval ka perenaised, lehmajälgedest kogutud mulda aga viidi oma koju, et lehmad ikka suvel palju piima annaksid. Karjasele anti meelehead (kakuke, keedumune vastavalt lehmade arvule). Mõnel pool keelati karjasel metsas tuld teha (Kadrina, Haljala, Vaivara), keelati ka vitsa murda, et kariloomad suvel jalgu ei murraks (Haljala, Simuna). Kui karjane karjast tuli, toimus kastmistseremoonia: talle visati kopsikuga vett, et ta kogu suve virge oleks, karjas tukkuma ei jääks ega sööks teda sääsed. 
Vene õigeusku rahvastiku seas on kevadine karjalask seotud kirikuga. Kariloomad aeti jüripäeval pühakoja juurde kokku või käis preester külas palvust pidamas ning loomi pühitsetud veega pritsimas. Hobustele seoti linte laka külge, veistele põimiti lillevanikuid sarvede ümber, ümber karja kanti ikooni, loomi löödi pajuurbadega, mida oli palmipuudepühal kirikus õnnistatud.

Karjapidamisega seotuna on jüripäev Virumaal üldse märksa olulisem kui jaanipäev, eriti võrreldes Lõuna-Tartumaa ja Võrumaa traditsioonidega. Nagu ristipäeval, nii ka jaanipäeval sai karjane vaba päeva. Sellest reeglist on hoolega kinni peetud veel 20. sajandi 30. aastate lõpul. Iisaku kihelkonnast on teateid venepärasest kombest ajada jaanilaupäeval loomad lauta üle nõgeste, et kurjad jõud lauta ei pääseks. Aasta kõige olulisem karjamaagia periood lõppeski jaanipäevaga; siitpeale vähenes ka piimaandmine: jaan võtab püti, jakob teise, laurits lakub põhja.

Mihklipäeva võeti 20. sajandi algukümnenditel karjatamisperioodi piiritähisena vähem arvesse kui jüripäeva. Karja siitpeale tavaliselt veel lauta ei tarvitsenud jätta. Küll aga oli käes aeg mõelda talvise loomatoidu jätkumise peale: Mihklipäeva õhtul pidi silmas peetama, et loomad karjamaalt tulles kõrsi suus koju ei toonud, muidu tõid nad loomatoidu puuduse majja (Jõhvi khk, 1931). Virumaalgi oli komme mihklipäeva tähistamiseks lammas tappa. Selle päeva lähistel paiknev vene õigeusu pokrov küll põllu- ja karjapidamisega otseseoses pole, kuid eestistunud külades on pokrovi pühitsemiseks tapetud kukki-kanu ning mihklipäeva nimetust käsitatud kui pokrovi eestikeelset vastet.

Veel 1981. aastal on Kadrina khk Läsna k arhiivile saadetud uskumus, et Kadri on karja kaitsja ning sel päeval tööd ei tehta - see rikuks karjaõnne. Simuna khk ennustati, et kui kadripäeval tuleb majja meeskülaline, sünnivad kevadel lauta oiniktalled. Kui mujal on kadripäev üks lambaniitmise tärmineid, siis Iisaku khk Sälliku k on valik veidi teistsugune: Lambaid kiideti neli korda-mardipäeval, vastlapäeval, kuremäepäeval ja enne nelipühi. (1962)

Komme kariloomadele jõulu ajal leiba viia on olnud Virumaal elujõuline veel 20. sajandi teisel poolel. Kohtla-Järve linnast pärineb soovitus kinnitada uue aasta ööseks laudaukse kohta pihlakavits, et see kaitseks karja tõbede eest.

\section{Kalapüük}

Kalendritähtpäevi kasutavad kalamehed ennekõike kalade kudeaja paikapanemiseks. Peipsi kalurite kõnepruugis hakkavat luts kudema kolmekuningapäeva aegu, ilmselt on see vana kalendriarvestuse järgi. Enamasti pole määratlemisel võrdluseks daatumid, vaid mingite fenoloogiliste nähtuste samaaegsus. Näiteks tähendab keltsanolk ja toomingahaug vastavalt jääkeltsa ajal ning toominga oitseajal kudevat haugi. 
Omapärast kevadise kalapüügihooaja alguse tähistamise kommet Iisaku kihelkonna Lemmaku, Rannapungerja, Kauksi ning Kuru külas mäletati ümbruskonnas päris hästi veel 1950. aastatel. Tegemist oli algselt maagilise toiminguga. Eelmise aasta püügist hoitud suur soolatud ja kuivatatud haug valmistati toiduks nimelt paastumaarjapäeval, mil haugi öeldi Peipsist Rannapungerja jõge pidi ülesvett kudemisrännet alustavat. Särje kudeaega arvestati jüripäevaga.

Enne jaanipäeva tuli Peipsist eemal asuvates külades hoolega tuule suunda jälgida. Teati, et kui on põhjatuul, tuleb rääbis randa ning kalameestelt saab heinaajaks head leivakõrvast. Rääbise kudemisaja orientiiriks peeti mardipäeva. Kirikupühadel Peipsiäärsed kalamehed järvele ei läinud, kardeti ebaõnne. Augustis, keset tindipüügi aega kehtis range kalapüügikeeld eelijapäeval (vkj 2. augustil), et Ilja-prohvet äikesetormiga keelu rikkujat ei karistaks.

Nii nagu Peipsi kalameestelt jaanipäeva eel rääbist saadi, käidi põhjarannikul mihklipäevaks räime - laaritsasilku ostmas (Haljala). Sügisel siirdusid Viru-Nigula rannast paatkonnad mihkli- ja mardipäeva vahel Narva-Jõesuu vetesse räime püüdma, soolatud silgud viidi Peterburi müüki.

\section{Kodused tööd ja toimetused}

Püüti tegutseda vanematelt inimestelt saadud õpetuste, vanasõnadeks vormunud traditsiooniliste suuniste järgi, kahjustamata majapidamist, pere ja enda käekäiku. Mitmed tõrjemaagilised toimingud olid just soovitatavad, lähtekohaks mingi analoogia. Seoses talviste ja kevadtalviste pühadega äratab tähelepanu naiste koduse käsitöö, eriti ketruse keeld kartuses kahjustada karja. Kogu jõuluajaks toomapäevast kolmekuningapäevani pandi koonladki peitu (Kadrina, Haljala, Vaivara, Simuna), ei tehtud ka villast tööd (Jõhvi, Iisaku, Simuna). Küünlapäeva kohta öeldi Iisakus: Sie oli sellepärast, et untidel ja rebastel olivad siis pulmad ja suvel oleksivad neile, kes kedrasivad, palju kahju teinud. (1959) Madisepäeval ei tohtinud kangast kududa, mürategev töö võiks suvel äikest välja kutsuda (Viru-Nigula), ketrajal oli karta karu- ja hundiohtu, nõelujat võis salvata madu, sest madisepäev on madude ärkamise päev (Vaivara, Rakvere, Simuna, Haljala), jahu sõelujat pidid kimbutama sääsed (Rakvere, Haljala) või herilased (Simuna). Vastlapäeva üldise ketrusekeelu põhjendusi on esile toodud enam Virumaa lääneosas, kõik on seotud karjapidamisega: lambad ei püsi karjas, ei sigi, neil kasvab vilets vill; sead ei püsi aedikus, neil kasvavad kõverad jalad. Paastumaarjapäevaks pidi ketrus olema kedratud, kangad kootud ja õhtusel tulevalgel töötamisel lõpp.

Soovitus tuua tuppa puukilde seostub Virumaal mitme kevadise tähtpäevaga: paastumaarjapäeva, palmipuudepüha e urbepäeva, suure neljapäeva ja 
suure reedega. Toojal pidi olema hea linnupesade leidmise õnn. Komme näib pärit olevat aegadest, mil veelindude ja kanaliste mune toiduks tarvitati.

Suurema usundilise kaaluga tähtpäevadel ei söandatud midagi majast välja anda, et mitte kahjustada pere heaolu. Näiteks suurel neljapäeval ei pandud kangast välja pleekima, et nõiaseltsi inimene seda ära nõiduda ei saaks (Rakvere). Eriti ettevaatlik tuli olla jüripäeval:

Jüripääval ei anta mitte miski majast välja, kui kua võeras piaks piibu piale tuld, ehk puutikka ammast kaevata, ehk nartsuräbalat ja lõngaõtsa sõrme kinni siduda, ehk nõnnaütelda "sõrme nartsu" tahtma, sedagi ei anta, ega kõhutäit süia ega miski suuremat asja ei antagi. Kui miski välja antud saab, siis piab kõik aasta välja antud ja maja kahju saama. (Iisaku khk, Tudulinna, 1889)

Kuna jüripäev on maa ärkamise tähtpäev, lähtub siit maasse puutumise keeld: enne jüripäeva palja jalaga maa peale astuda ei tohi (Haljala, Rakvere, Väike-Maarja). Seevastu ujumaskäimist enne jüripäeva on peetud tervistavaks, teateid on kõikjalt peale Vaivara ja Iisaku khk idapoolsete külade.

Sügiseste koduste toimingute seas äratab tähelepanu hingedeajale omane lahkunud omastele koduse vastuvõtu korraldamine eestistunud ja luteri usku siirdunud läänemeresoome-vene segarahvastiku asualal. Teateid sellisest esivanemate austamise kombest on peamiselt Iisaku khk (paar teadet ka Torma khk). Nimetus midrusk märgib veneõigeusu midruskipäeva (26. oktoober). Kiriklikult on tähistatud püha Dmitri mälestuspäeva vanemate laupäevana - siit tulenevad ka muutused kuupäeva märkimisel. Kui Mulgimaal pandi hingedele toitu välja kõrvalisse kohta ja erinevatel aegadel, siis Virumaal kaeti kadunukestele laud eluruumis. Vanemate kirjelduste järgi (vrd Truusmann 1895: 16 (21)) leidis aset nende laudakutsumise rituaal. Oma pere liikmed seisid seni vaikselt eemal, kuni peremees külalised taas välja saatis. Kas sõnad, nagu Sõite, jõite, kõht sai täis, minge on olnud traditsiooniline lausung, või on tegemist trükistes leviva kultuurikirjeldusliku fiktsiooniga, pole kuigi selge, ent sõnalist pöördumist teadis 64aastane informant mainida veel 1935. aastal: Teevad mitu toitu, panevad lauale ja käivad ise ümber ja kutsuvad surnuid sööma, et sööge aga nü̈̈d ja sööge aga nüüd. Kui arvavad, et surnud on ju söönud, siis hakkavad ise sööma (Pärniku k). Siintoodud kombekirjeldus käib Kuru küla kohta, kus midrusk on ühtlasi ka elavaid suguvõsaliikmeid kokku toov külapüha.

Talve tulekul loeti tubast ketruse ja käsitöö hooaja algust küll mitmel pool mardipäevast, kuid sel päeval ei kedratud. Simuna kihelkonnas öeldi, et kui siis villast asja kududa, kaob lambaõnn. Põhjarannikul oli jaguajal tubase käsitöö keeld lausa valdav, põhjenduseks karjakahju. Kurjade jõudude tõrje seostub kõige enam jõulutsükliga. Eesti piirialal on see hästi märgatav ristide tõmbamises 
akendele, ustele, piitadele, väravatele jne kurjavaimu, tondi, kodukäija, nõiduse, üldse kõige halva tõrjeks kolmekuningapäeval. Mida enam sisemaa poole, seda eelistatumad ajad selliseks tõrjemaagiaks on jõulu- ja vana-aasta õhtu.

\section{Toidud ja joogid}

Paljude tähtpäevatoitude näol on tegemist kunagiste ohvritoitudega või vähemasti rituaalsete toitudega, mille valmistamise otstarvet aitab selgitada tähtpäeva üldine usundiline taust. Kõige suuremad söömapühad olid ja on praegusajalgi jõulud. Jõuluajal tuli rikkalikult süüa, jõululaupäeva õhtul koguni 7, 9 või 12 korda, et toitu samuti jaguks kogu eelolevaks aastaks, Lüganuse khk kirjapaneku järgi: õhtust ööd magati veidi, siis tõusti üles ja söödi. Rikkalik toidulaud kuulus ka mihklipäeva, veneõigeusulistel lihavõttepühade ning külapühade tähistusse.

Kogu Põhja-Eestis oli seapea oluline jõulutoit; tervelt kolmandik teadetest on laekunud Virumaalt. Seapea keedeti enamasti hapukapsaga. Süldikeetmine on rohkem 20. sajandi komme. Ka tähtsamate kesktalvepühade - tõnisepäeva ja küünlapäeva toiduks on Virumaa tavandis tervelt keedetud ja üleküpsetatud seapea või pool pead. Seoses küünlapäevaga on sellekohaseid teateid rohkem Ida- kui Lääne-Virumaalt. Vastlapäevaks keedeti oa- või hernesupp seajalgadega. Komme on suutnud püsida läbi 20. sajandi, kuid põhjendus kuulub 19. sajandisse: et sead suvel koos püsiksid, tuli perenaisel seajalakondid lakka viia ning sealt paastumaarjapäeva hommikul maha tuua (Haljala, Simuna), või hoiti need alles järgmise vastlapäevani, et seakasvatus oleks edukas (Vaivara). Seajalakondist uriluu valmistamise põhjusi mainitud pole. Künnimehelegi on toiduks pakutud seapead (Lüganuse, Jõhvi); seasaba sai odrakülvajale, et kasvaks ilus oder (Iisaku).

Lambaliha söödi mihklipäeva toiduks, see on olnud lõikus- ja karjasepüha põline traditsioon, välja arvatud vene õigeusu mõjulisel alal, kus on kombeks tähistada pokrovi kuke- ja kanaliha söömisega. J. Truusmann (1895: 16 (22)) märgib kanaliha söömist ka mardipäeval seoses surnutekultusega: praeti kana, et vaimud tulevad sööma, pererahvas lahkus seniks ruumist, toidu ülejääk söödi hiljem ise, kanaluud peideti aampalgi alla. Linnuliha (kana-, pardi-, haneliha) küpsetamine mardi- ja kadripäeva toiduks näikse lähtuvat põlistest soomeugri tavadest, Lääne-Euroopa mardi-kadrihane söömise komme ulatus Virumaale üsna hilja ning põgusalt.

Kõrgelt hinnatud püügikala haugi toiduksvalmistamisest oli juba juttu seoses kalastajauskumustega paastumaarjapäeval. Tegemist on Peipsi ümbruse vene kalurite kombega, mis külade eestistumisel edasi püsis. Suur haug lõigati 
lõhki selja pealt, soolati ja kuivatati spetsiaalselt tähtpäevatoiduks, eeltuleval kevadel see leotati, keedeti ning tehti soust peale. Rituaalset einet pakuti ka külalistele ja seda nimetati kuiva havi söömiseks. Veneõigeusulistele on Peipsi kalad oluline paastutoit, eriti suure lihavõttepaastu ajal, mil toidulaud niigi varakevadiselt kehvapoolne. Jõhvist pärit teate järgi püüdsid need, kes paastu ei pidanud, ikkagi kala süüa suurel neljapäeval ja suurel reedel.

Teraviljatoitude seas on esmatähtis rukkileib. Et jõuluks valmistati eriline leib, selle kohta on kirjeldusi mitmelt poolt. Vaivara ja Jõhvi kihelkonnas on märgitud, et tainas vooliti kõrgeks pätsiks, sisse vajutati augud, Haljala khk rist. Kadrina, Haljala, Väike-Maarja, Simuna, Jõhvi, Vaivara khk nimetati sellist ka jõuluorikaks. Mõnel pool vajutati "orikale” veel sõrmusega silmad pähe ja aidavõtmega jäljend selga. Jõulusöögiks seda ei pruugitud.

Kunstipidajad aga tegivad peale muude asjade veel omale ühe suure leiva ja nimetasivad seda jõuluorikaks. See nõndanimetatud orikas seisis kõige pühade aja laua peal ilma puutumata. Kui siis pühad mööda jõudsivad, siis viidi see nõndanimetatud orikas aita viljakirstu ehk salve, kus ta siis kevadeni seisis, see on selle päevani, kui kari välja lasti. Siis võeti ka orikas kirstust või salvest välja ja leigati keskelt katki. Oli nüüd orikas seest hallitama läinud, siis oldi mures, et loomadele sel suvel õnnetus saab tulema. Aga kui orikas mitte hallitand ei olnud, siis rõomustati, et loomad heaste korda saavad minema. (Kadrina, 1894)

Narva päritoluga teates on otsesõnu öeldud, et kui leib kogu jõuluaja laual seisab, jätkub seda perele kogu aastaks ja lehmad annavad hästi piima (1892).

Idapoolse Virumaa pühadetoitude seas tuleb kindlasti nimetada pannkooke, venepäraselt pliinisid. Tähtpäevade loend on järgmine: küünlapäev, vastlapäev, tuhkapäev, lihavõtted, nelipühad, mihklipäev, mardipäev, kadripäev, jõulud. Kõige kaugemale lääne pool ulatub läänemeresoome ja ka Volgamaa sugulasrahvaste populaarne koogiküpsetamise komme seoses vastlapäevaga: LääneVirumaalt on teateid Simuna, Viru-Jaagupi, Rakvere ja Väike-Maarja khk. Ka tuhkakooki on söödud mõnel pool Lääne-Virumaal ja ka Põhja-Tartumaal. Iisaku kihelkonna Pagari külast pärineb meenutus, et jõululauale küpsetati kaerajahu- ja tatrakooki. Sälliku külast pärit kirjelduse järgi küpsetatud kaerajahukooke, pandud 1-2 kooki alla põhjaks, lusikaga võid vahele ja 1-2 kooki peale, keeratud siis kõik kokku ja kastetud veel või sisse. Võrreldes sisemaaga on Ida-Virus rohkem harrastatud ka piirakate küpsetamist tähtpäevatoiduks: kohupiimapirukad lihavõtteks, nelipühadeks ning jaanipäevaks, porgandi-, kapsa-, kaalikapirukad, soolapekitäidisega pirukad sügisesteks tähtpäevadeks, jõuluks ning külapühadeks. Magushapu- ehk peenleib, odrakarask ehk paasik (nimetus on tuntud Ida-Viru kihelkondades), sai, mitmesugused kuklid, 
odrajahust kokurgid kuuluvad mistahes tähtpäevade menüüsse (vt ka Moora 1991: 107-108). Vastlakuklite küpsetamise kohta on esimene teade Rakvere linnast 1934. aastast. Jõuluks küpsetati präänikuid, jõulupiparkooke õpiti tegema 20. sajandi esimesel poolel.

Odra (kruupide, tangude, jahu) kasutamine pole Virumaal nii populaarne kui Eesti lõunaosas, kuid karjandusmaagilisest tangupudru söömise kombest loomalaudas on kõige ilmekamaid pärimusteateid Jõhvi ja Vaivara kihelkonnast. Külanoored käisid kadripäeval perest peresse, neile pakuti putru lambalaudas, et head lambaõnne tagada. Nagu paljudest maagilistest toimingutest, kujunes sellestki 19. sajandi teisel poolel pigem meelelahutus. Kirjelduses Jõhvi kihelkonna Toila külast on märgitud, et külastuste juurde kuulus laudas õlgedel olles kariloomahäälte matkimine (määgimine, ammumine, hirnumine, röhkimine), perenaine pakkus lausa mitmeid toite ja ka ôlut ôli enamiste selle jauks pruulitud (1892). Jõulutoiduna on tanguputru mainitud Viru-Nigula, Lüganuse, Jõhvi, Iisaku ja Simuna khk päritoluga kombekirjeldustes. Siia kõrvale võib tuua teise, üldlevinud mooduse odratangude kasutamiseks - tanguvorstid. See on kõige populaarsem jõulutoit, mille valmistamise komme on maakodudes püsinud sama kaua kui seakasvatus.

Muna kui algava elu sümbol kuulub kevadisse aega, tavandis on oluline koht muna söömisel ja kinkimisel eriti lihavõtte- ja nelipühadel ning jaanipäeval. Muna keedeti kündjale esimesel künnipäeval ning karjasele esimesel karja väljalaskmise päeval. Muna kuulub spetsiaalse lihavõttetoidu - pasha koostisse; eesti peredes on tehtud munavõid nii lihavõtteks kui ka nelipühiks. Keedetud on ka munarooga:

Minu ema (Oonurme külast) tegi alati ristipäevaks munarooga. Munad klopitakse ära, pannakse piima juurde, valatakse potti. Segada kohe, kui hakkab peale tõusma. Siis paned veel tilga külma piima, katad kaanega ja las seisab, ei tohi enam liigutada. Siis ongi valmis. (Iisaku, 1962)

Piimasaadustest kuuluvad tähtpäevamenüüsse kohupiim lihavõttepasha valmistamiseks ning pirukakatteks nii lihavõtte-, nelipühade kui ka jaanipäevatoiduna. Et jõululaud pidi olema võimalikult rikkalik, seda peab silmas üks Lüganuse kihelkonnast kirja pandud kujundlik argumenteering: Kui jõulul ei olnud võid laual, siis jooksid lehmal kogu suve silmad vett, et temast ei olnud lugu peetud (1930).

Mõningast aed-ja juurviljatoidu eelistust on märgata sügiseste põllutöö lõpu tähtpäevadel, nt Kadrina kihelkonnast on teateid kaalikate küpsetamisest tuha sees mihklipäeval. Mardi- ja kadrisantidelegi pakuti kaalikaid, ube-herneid, ounu. Herneid on mardianniks antud nii toorelt kui soolaga keedetult. Ainult Virumaalt - Lüganuse ja Simuna khk - on teada keeld kadripäevaks kapsasuppi 
keeta, et kanad ei hakkaks kevadel kapsataimi nokkima. Veneõigeusulistele on aedvili hinnatud paastutoit, eriti on lugu peetud hapukapsast ja -kurgist ning sibulast.

Tähtpäevalauale kuuluvad joogid on õlu ja viin. Paastumaarjapäeval ostsid mehed naistele maarjapuna, siis pidi kasvama hea vili, öeldi ka, et joojal on kogu aasta põsed punased ja sääsed teda ei kiusa. Jooke pruugiti jüripäeval ja jaanipäeval, mardi- ja kadripäeval. Koduõlut pruuliti mihklipäevaks, jõuluõlu pandi käima juba enne toomapäeva (Kadrina, Haljala, Rakvere, Viru-Jaagupi) või siis peeti seda aega just liiga varaseks (Simuna). Jõuluõlle tegemine kuulus meeste tööde hulka ning nõudis vilumust:

Mehed tõivad terve külimitutäie linnasejahu, segasid need vannis ära ja panid pannide ja pottide peale ja siis kaljahauded kuuma ahju. Varsti täitis ruumi magus lõhn ja see näitas, et makid juba küpsema hakkasid. Ahjust välja võttes olid mõned pannid vedelikku üle ajanud ja need linnaste kompvekid olid laste maiusroog. [---] Riistad pesti kuuma veega, loputati siis külma veega ja jäeti siis nõrguma. Olid riistad tahenenud, siis seadis peremees kaljaastja jalgade peale ja paigutas astja põhja puuresti. Selle peale pandi õlekord kahekihiliselt risti. Nende peale tulivad kinnituseks sarapuupulgad ja kõige üle veel harv takune riie. Nü̈̈d lauti kuumad hauded sinna peale ja siis juba peale kuum vesi. Varsti lasti sealt virre välja ja kui see oli rõõsa sooja piima taoliseks jahtunud, lisati sinna pärm juure. (Rakvere khk, Mõdriku k, 1970)

\section{Meelelahutus, kooskäimised}

Nuudipäeva ${ }^{11}$ pühitsemine pärast kolmekuningapäeva jõuluaja lõpu pühana on Virumaa põhjarannikule jõudnud kultuurilaenuna Soomest. Tähtpäeva nimepühakuks on Taani hertsog Knud. Kui Loode-Eestis käisid mehed nuudipäeval õlest keeratud nuutidega perest peresse õlleankrutelt punnisid maha peksmas, siis Haljala kihelkonna Vergi külast kirja pandud teate järgi pandud seal õlleankur kelgu peale ja mindud õlgnuutidega peredesse iivanuuti peksma, et ankrusse õlut saada. Lüganuse pärimusteate järgi mindud kõrtsi, õletuustid peas, vanad luuad ja vihad seljas, pühasid välja ajama ning mehed peksnud kõrtsis üksteist nuutidega. Niisuguse jõululõpetuse kohta on soomlastega ühine vanasõna: Hea toomas toob jõulud, paha nuut viib.

Kevadtalviste kõrtsiskäimiste kohta on tähtpäeva tähendusest lähtuvalt muidki kujundlikke seletusi. Tõnisepäeval murdsid mehed talve selga katki, küünla-maarjapäeval käisid Väike-Maarja kihelkonna naised kõrtsis lüpsikuid turbutamas, et lehmad palju piima annaksid. Kadrina kihelkonna Ojaveski 
külas mäletati veel 1969. aastal, et Viitna kõrtsis käidud talve selga pooleks tallamas küünlapäeval. Jõhvi kihelkonna teate järgi käisid perenaised liugupäeval kõrtsis viinaga lina juuri kastamas; mida kaugemal käidi, seda pikem pidi kasvama lina. Liulaskmise seostamine linakasvuga kestis Teise maailmasõjani. Skarjatina külas kogunesid noored mehed maslenitsa e võinädala ajal kooskäimiskohtadesse tüdrukuid passima, neid leivalabidaga tagumikule patsutades öeldi, et see on pliinide küpsetamine. Koos lauldi, tantsiti ja lasti liugu kogu võinädala kestel. Jõhvi kihelkonna Saka külas kogunesid noored merejääle jalaliugu laskma.

Teateid tuhkapäeva viguritest on Simuna ja Viru-Jaagupi kihelkonnast. Nimelt püüti teise peresse üle ukse tuppa kotiga tuhka visata või seda üle põranda laiali ajada. Kui õnnestus pahandusetegija kätte saada, ootas teda karistus: tal torgati käistest puukepp läbi, aeti sinepit suhu vms.

Tüdrukud, keda noormehed olid urbipüha varahommikul pajuurbadega urbimas käinud, pidid urbijaile kas kohe või lihavõttepühadel muna, raha või kommi andma. Venelaste seas ja eestistunud vadja-isuri-vene rahvastikuga külades oli urbimaskäimine veel 20. sajandil üsnagi populaarne. Iisaku kihelkonna Vaikla külast on kirjeldusi venepärasest andide küsimisest akende all käimisega.

Lihavõtte esimese püha ommikul enne päikesetõusu käidi kukkest. Enamasti külapoisid, aga vahest mõni naisemeeski üppas välja. Läksivad teiste omade akna taha ja “Kukeleegu! Kukeleegu!” Ega miski, pidi muna pihku panema, muidu ei jättand järele. Meni korjas nendamoodi, kui küla jõudis läbi käia, ulka mune. Aga kui päike juba nena välja pistas, oli keik kukest olemine läbi. (1959)

Ühe varasema teate järgi olnud poisid ja mehed sealjuures seatud kuke moo$d i$. Kirjeldustest ilmneb, et sel viisil käies ei eeldatud, et munad oleksid juba keedetud ja värvitud, kuid kogused olid suured: poisid tõid 70 toorest muna; mune värviti silmapesukausi täis. Peipsi äärses Remniku külas meenutati, et lihavõttemunad värviti enamasti punaseks ja lapsed käisid neid 20. sajandi algukümnenditel järve kaldaliival veeretamas. Mõnel pool valmistati lastele õõnsast puust munaveeretamise rönn. Virumaa munapühi iseloomustab komme kinkida teistele inimestele mune, suhteliselt kaua püsis munavärvimine ja kinkimine nelipühadeks, küllaminekul võeti kaasa mune ja saadi neid vastu. Munade värvimisest kaselehtedega jaanipäevaks on teateid pea kõigist LääneVirumaa kihelkondadest. Huvitavaid andmeid on kiikumise kohta. Vasknarva valla Verhnjeje Selo lastele valmistati veel 1930. aastatel lihavõtteks nöörkiik. Rohkem küll Järva-, kui Virumaal tunti omapärast lauahüppamise kommet teine teises plangu otsas üles-alla õotsudes. Teateid on Virumaa läänepiirilt Kadrina, Haljala ja Väike-Maarja kihelkonnast. 


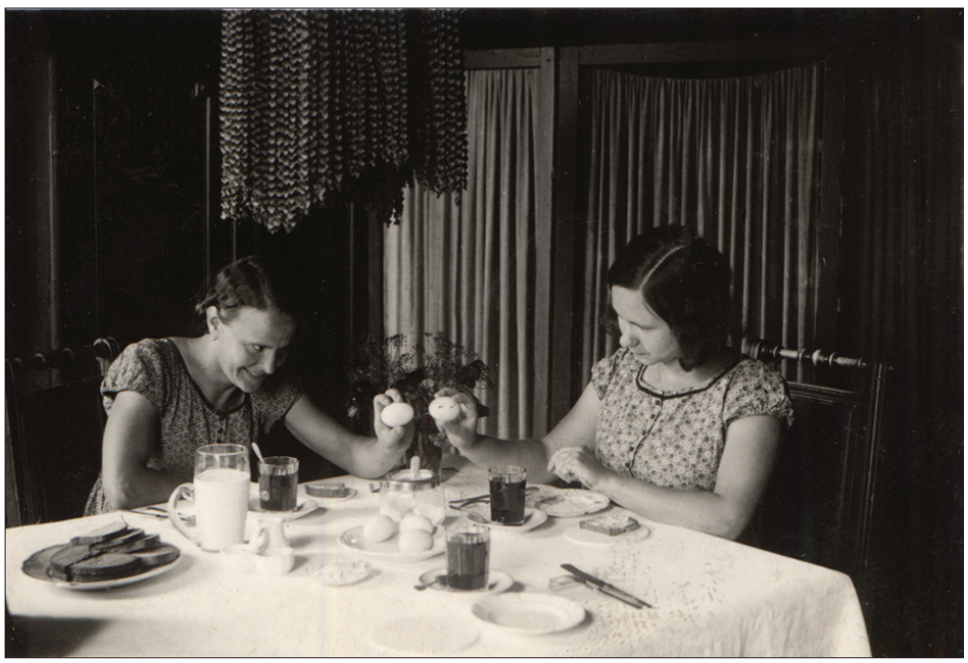

Foto 2. Lihavõttemunade koksimine, Kadrina khk. Foto Richard Viidebaum 1933. ERA, Foto 217.

Paastumaarjapäevast punajoomistki on Jõhvi kihelkonnas nimetatud lüpsikute turbutamiseks, samuti nimetati jaanipäevast Kaarli kõrtsis käimist Rakvere kihelkonna Raudlepa külas, kuid kõige suuremaks pidutsemispäevaks kujunes Ida-Virumaal venepärase naistepüha eeskujul ikkagi jüripäev. Ühe naistepeol osalenu jutustuse järgi küpsetasid Kauksi küla naised kaasavõtmiseks mitut seltsi pirukaid ning kogunesid oma kompsude ja korvidega kokkulepitud peresse, kus oli rohkem ruumi. Kui naiste seltskonda sattus meesterahvas, tõsteti ta üles. Kes viina ostis või raha andis, võeti kampa. Pill mängis, naised tantsisid. Samuti pidutseti Kuru külas, koos olid abielunaised ja mõned tüdrukud, õhtuks tulid ka mehed seda nalja vaatama (1962). Sälliku külas jutustas 84aastane naine 1962. aastal, et vanad naised küll käivad veel koos, kuid noored enam mitte.

Kõige kuulsam pidutsemispaik oli Jõhvi ja Iisaku kihelkonna piiril Illuka valla Raudi mäel. Siia koguneti mitmetest kaugematestki eesti ja eestistunud küladest lüpsikuid turbutama. 20. sajandi algukümnendi kombekirjeldustest ilmneb, et siin said vanemad laulunaised volilt oma regilaulurepertuaari kuuldavale lasta. Raudi pidutsemiste erijooneks oli puust mõlade ja mändadega puutünnis klobistamine võitegemislaulu "Kokku, kokku, koorekene" saatel. Kaasa võeti ka puulähkreid, milles vett loksutati. Siit tuleneb kooskäimise üks kujundlikke nimetusi võitegemine. Seda kommet kui läänemeresoome-idaslaavi kalendritavandi sümbioosi näidet on pikemalt kirjeldanud H. Tampere (1965: 237-245).

Jüritule tegemine pole Virumaal nähtavasti kunagi olnud nii populaarne kui Lõuna-Eestis. Kui Eesti Vabariigi aegadel hakati suvetöölepinguid sõlmi- 
ma 1. maist, kujunes maituli organisatoorseks laulu, pillimängu ja tantsuga vabaõhupeoks. Maiõhtuid peeti ja nelipühadeks seati kiik korda enamasti jaanituleplatsil. Selline oli pea igas külas.

Tuntumate kogunemiskohtade seas on nimetatud Vaivara kihelkonna Sinimäge, Narva jõe äärset Olgina mäge, Jõhvi kihelkonnas oli tuli Ontikal paepealsel mererannikul, Edivere linnamäel ja Kuremäe vaatetorni juures, Iisaku kihelkonnas Koldamäel, Vaiklas jõeäärsel platsil ja Tudulinnas linnamäel, Viru-Jaagupi kihelkonnas kiriku taga kaasikus, Väike-Maarja kihelkonnas Punamäel, Kadrina kihelkonnas Kallukse kiigemäel. Lüganuse kihelkonnas Aa rannas süüdati tuli rannavallil, kust olnud mereäärsed tuled näha kuni Viru-Nigula kihelkonna Letipea neemeni, üle mere paistnud isegi Tütarsaare tuli. Jaanitulelt ei hoidnud kõrvale ka härrasrahvas: Püssi krahv käskinud tule teha pargi aia taha, Kiltsi härra lossi lähedale veski juurde, Mõdriku härra lasknud moonakal lõkkepuid hobusega mäele vedada, Palmse krahvi korraldusel paugutatud koguni kahurit ning mindud lossijärvele sõudma. Kiigeplatsidele ehitati tantsupõrandaid, mõnel pool seati üles värvilisi laternaid ning postide ümber vanikuid. Ringmängud ning mõisajaanituledel propageeritud jõu-ja osavusmängud vahetas ajapikku välja koorilaul, pillimäng ja paaristants. Tantse on informandid nimetanud tosina jagu: polka, valss, labajalg, viruvalss, viru mage, ringitants e perekonnavalss, leilender, opsaa, tustep, krakuljak, padispaan, vingerka.

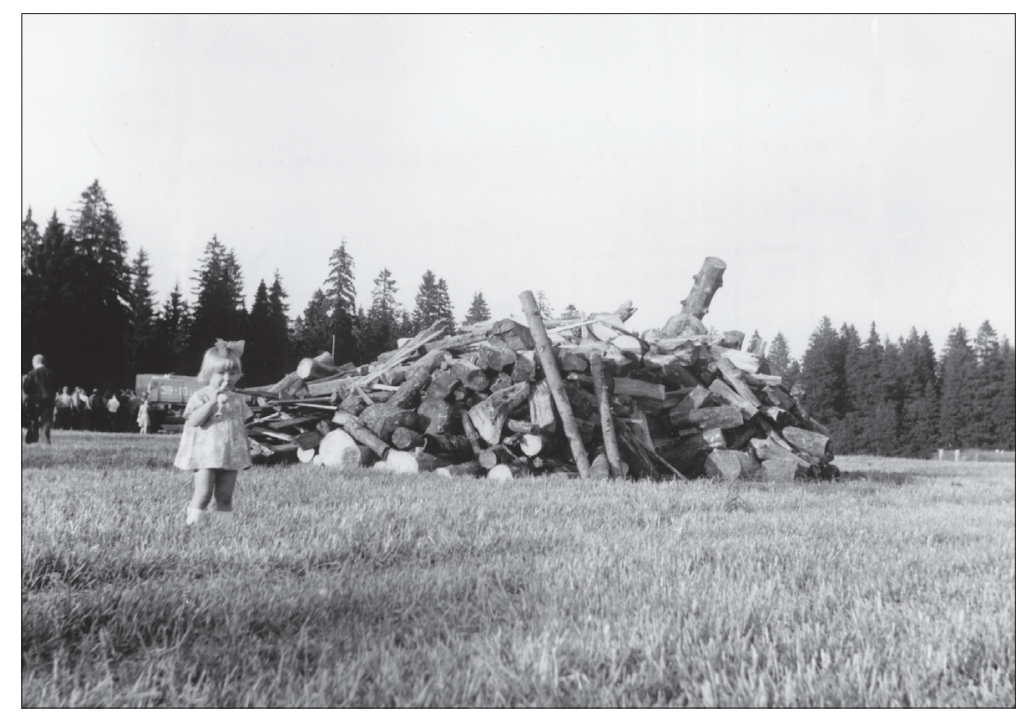

Foto 3. Ühisjaanituleks on kuhjatud üle $30 \mathrm{rm}$ puid. Väike-Maarja khk. Foto Mall Hiiemäe 1979. ERA, Foto 12407. 
Teateid selle kohta, et heinamaarjapäeva eelõhtul kogunesid noored küladest ühiseks murakalkäiguks Muraka raba serva - nõmmedele, rabaäärsetesse peredesse aega veetma, laulma, ringmänge mängima ja tantsima, on Muraka raba ümbrusest: Oonurmelt, Rajalt, Tudulinnast, Mõisakülast, Sahargu, Roostoja, Lõpe ja Saarevälja külast, juhtumisi ka veel Lüganuse mailt. Kalendrireformiga 1918. aastal osutus see töökeeluga päev murakate valmimise suhtes liiga varaseks, ometi püsis ühiste murakalkäimiste komme Teise maailmasõjani.

Eesti mihklipäeva ja vene õigeusu pokrovi meelelahutuslik pool on üsna sarnane, nt Iisaku khk Kauksi ja Liiva eestistunud külades eesti tavade järgi rikkalik toidulaud, vene tavade järgi vastastikused külaskäigud rohke kostitamisega, aga ka nimepäeva tähistamine ja kõrtsiskäik:

Pokrov - mihklipäev. Teeb õlut, veini, praazdnik teeb. Isa nimi Mihkel, poeg ka Mihkel. Ennemast olid kortsid, tehti veike praazdnik, lähevad poisid-tüdrukud kortsi, tantsivad, patseerivad ja tulevad tagasi. (Iisaku khk, Vaikla k, 1931)

Järgmises kirjelduses võrdleb informant mihklipäeva vene õigeusu midruskiga, varjamata oma suhtumist talle võõrastesse pühitsemisviisidesse:

Sie on sügiste tüöde lõpp, nigu siin ennevanast õli mihklipäev sügiste tüöde lõpp. Ega siin [Tudulinna pool] seda põle, midruskit pietakse Kurus. Kurus ôli ebausklikkusi väga palju, praegugi on viel midrusk, siitki käivad sial külapühal. Süemine, juomine, tantsimine sial siis on. Külaline võetakse vastu. Käivad ühest perest teise, igalpuol süövad ja juovad. Kui on küla läbi, siis on pidu õtsas. Poluvärtsikud on, on saand ebamõtteid, mitmet asja austavad ja pühitsevad. (Iisaku khk, Mõisaküla, 1956)

Üsna hõlpsasti võtsid usuvahetajad üle mardi- ja kadriskäimise kombe, sest andide palumine perest peresse käies pole vene kombestikus võõras. Iisaku kihelkonna Jõuga külast pärit andmetel laulsid sandimardid ka vene keeles. Alajõel tehtud seda balalaika saatel, Uuskülas nimetatud sanditajaid santimarti ja Liiva külas santiki. Tantsud olid samad mis jaanipäeval, pillidest on nimetatud kannelt, viiulit, karmoskat, lõõtsa, balalaikat, suupilli. Virumaa lääneosas (Kadrina, Haljala, Rakvere, Väike-Maarja, Viru-Jaagupi, Simuna khk) säilisid vanad põhjaeestilised tavad - rollimäng, perekonnaks maskeerimine, loomamaskid, pulmapruutpaar, mustlased, kadritite ristimine ning toitudega järelpeo pidamine kauemini kui idapoolsetes piirkondades. Ida-Viru poolel on sanditajatele pakutud ka pannkooke.

Jõulupuukomme jõudis Virumaale nagu mujalegi Eestis mõisa ja koolide kaudu 19. sajandi viimastel kümnenditel ning kodunes peredes 20. sajandi algukümnenditel. Esimene teade mälestuskuuse viimisest kalmistule on 1934. aastast Rakvere linnast. Narva raekoja platsile püstitati poissmeeste 
jõulupuu 1939. aastal. Hobusega mööda küla sõitmised on enam populaarsed olnud maakonna idaosas. Sõitmas käidi, pill kaasas, kolmekuningapäevani, peredesse jäädi ka ööseks. Õnnevalamine ja tulevase ennustamise võtted olid kogu maakonnas ühesugused, kuigi mitte ühtviisi populaarsed.

Aasta lõpust on esile tuua üks soomemõjuline meelelahutus. Nimelt käidi Haljala ja Vaivara kihelkonna mõnes rannakülas tabanipäeval (26. detsember) tabanit ajamas: koguti sööki-jooki, et kuhugi tallu kokku tulla meelt lahutama ja tantsima. Haljala kihelkonna Vergi ja Mustoja külas käinud nõgiste nägudega noormehed lauldes talust tallu ja pühkinud kadakaokstega ahjuaugud puhtaks. Saadud annid söödi koos. Vaivara kihelkonna Ridaküla tabaniajajad hüpanud ja karanud, õlest kiivrid peas ja karvupidi kasukad seljas.

\section{Kalendritavandi muutumine 20. sajandil}

20. sajand tõi põlisesse talurahva kalendrisse hulgaliselt muutusi, mille põhjustas suhteliselt stabiilse usundilise maailmapildi üha kiirem taandumine, feodaalkorra lõppemisest tulenenud sotsiaalmajanduslikud muutused, 1918. aasta kalendrireform, mitmed ühiskonnaelu vapustused: sõjad (Esimene ja Teine maailmasõda), okupatsioonid, ümberasustamised, ühismajandite loomine, repressioonid. Nõukoguliku ideoloogia kohustusliku sissetoomise kalendritavandisse lõpetas Eesti taasiseseisvumine 1991. aastal. See tõi kaasa kultuurikontaktide avardumise Lääne suunal ning vaba voli tähistada kirikuga seotud pühi.

Kui veel 1970. aastatel püsisid maaelanikkonna vanema põlvkonna mälus talupojakultuurile omased kalendritarkused, siis noorema põlvkonna elulaad nende säilimist ei soosinud. Eriti Ida-Virumaal sai mõjuriks linnastumine, tööstuse kiire areng ja migratsioon. Sajandeid aastajaotustähisena, töödekalendri orientiirina, sotsiaalsete suhete reguleerijana vägagi arvestatavad tähtpäevad, nagu tõnisepäev, paastumaarjapäev, jüripäev, nelipühad, jakobi-, lauritsa-, pärtli-ja mihklipäev kaotasid oma varasema positsiooni juba 1940. aastatest ega saanud ka uut tähendust. Oma meelelahutusliku laadi poolest püsisid tähistatavate seas vastlapäev, nõukogude perioodil juurutatud naistepäev (8. märts), jaanipäev, mardipäev, kadripäev ja aastavahetuse markerina näärid.

20. sajandi lõpukümnendi kalendritavandis sai laste- ja noortepühana rahvusvahelistel eeskujudel omaseks valentinipäev (14. veebruar), nõukoguliku 1. mai kui töörahva solidaarsuse päeva vahetas eesti rahvusest elanikkonna seas noortepühana välja volbripäev (1. mai), taaselustati emadepäeva ja isadepäeva 1920.-1930. aastatel välja kujunenud traditsioonid. Kaua unustuses olnud tähtpäevade seas leidis tähelepanu hingedepäev (2. november), ning lausa suurejooneliseks teisenes jõuluveetmine, liites endaga nii advendiaja päkapikumüsteeriumi kui jõuluteemalised koosviibimised. 
Kooliõpilaste vastustest 2007. aastal korraldatud küsitlusele selguvad nii tähistusviis kui noorte hinnangulised eelistused. Uusaasta vastuvõtu populaarseim üritus on rakettide laskmisega ilutulestik. Sõbrapäevast kirjutab Põlula koolitüdruk: Eriti meeldib kõigile noortele valentinipäev, see on tore päev, kus saab sõpradele kingitusi teha ja nendega niisama toredasti aega veeta. Päevale annavad sisu veel üksteisele kaartide saatmine. Valentini ja Valentina valimine, punasesse rõivastumine, lühendatud koolitunnid, mitmesugused võistlused. Valentinipäeva, vastlate, mardi-ja kadripäeva ning jõulutähistuses on esile tõstetud oma klassiga korraldatud üritusi. Aprilli on tehtud nii oma pere ringis kui koolis (Pudivere, Koonu, Assamalla k), Väike-Maarja gümnaasiumist on teade anekdootide jutustamise võistlusest. Ülestõusmispühade munavärvimised näivad teismeliseeas juba vähem huvi pakkuvat. Jüripäeva puhul jürijooksu korraldamisest on juttu samuti Väike-Maarjast, nimetatud Georg Lurichi jooksuks, Iisakus oli jürijooksu võitjale auhinnaks tort, volbriõhtul tuldi koolimajast rahvamaja juurde lõkkeõhtule ühise rongkäiguga ja nõiarõivais. Kodustele jaaniõhtutele annab paljudes kirjeldustes sisu šaslõkiküpsetamine ja grillimine oma perega või külalistega, võimalusel käiakse ka suurel jaanitulel: Jaanipäeval lähme me Porkunisse ja pidusse suure lõkke äärde, teeme võistlusi ja igast sellist jama (Väike-Maarja). Mardi- ja kadripidu on üksmeelselt nimetatud diskoks. Jõhvist saadetud ankeedivastuses on mainitud isadepäevaga seoses poistenädalat ja vastavalt naistepäevanädalat, mil toimub ka disko populaarseima poisi või tüdruku valimisega. Jõulupühadega seoses meenutatakse külaskäike, oma klassis ühiselt korraldatud jõululauda ning heategevuslikku jõululaata.

Teistest rahvustest uusasukate kalendripilt on suhteliselt ebaühtlane. Kõige valdavamalt kuulub tähistamisele uue aasta tulek. Uue regionaalse kalendripühana väärib märkimist veneõigeusu tatjanapäev (12./25. jaanuar), mida tähistatakse traditsioonilise tudengipühana Tartu Ülikooli Narva kolledžis alates 1990. aastate keskmest. Selle püha põhiliini moodustavad initsiatsiooniriituse elemendid esmakursuslaste tudengikspühitsemise, ühise rongkäigu ning pidutsemisega. Vanapärase elulaadi säilitanud veneõigeusku püsielanikkonna tugevalt kirikuga seotud rahvakalendrisse 20. sajand kuigi olulisi uusi jooni ei toonud.

\section{Kokkuvõtteks}

Virumaa rahvakalender kuulub Põhja-Eesti kultuurivaldkonda, kuid muistsele Põhjala maaviljeluspiirkonnale omased ühisjooned kas pole ulatunudki Virumaa idapoolsetele aladele või on hakanud aastasadadega taanduma ja naaberrahvaste - peamiselt läänemeresoome ja ida-slaavi - kultuuri ning erineva 
kirikliku kuuluvuse mõjul segunema. Kombestikuelementide võrdlusel ilmneb, et mõtteline eraldusjoon kulgeb Virumaal piki Viru-Nigula ja Lüganuse khk vahelist piiri ning ulatab Avinurmeni.

\section{Kommentaarid}

1 Artikkel on seotud HTM uurimisprojektiga "Folkloor kultuurilise kommunikatsiooni protsessis: ideoloogiad ja kogukonnad" IUT 22-4.

${ }^{2}$ Bogoroditsa (vn jumalasünnitaja), ka uspenije, uspensk on veneõigeusu kirikukalendris Jumalaema uinumise püha, eesti rahvakalendris rukkimaarjapäev.

${ }^{3}$ Poluvernik, poluvertsik (vn poolusklik), rahvakeeles kasutatud eri kultuuridest mõjustatud isiku kohta.

4 Tabanipäev - roomakatoliku kiriku kalendri püha Stefanuse mälestuspäev.

5 Makavei - õigeusukirikus märtritest vendade Makabeide mälestuspäev.

${ }^{6}$ Pokrov - õigeusukiriku kalendri Jumalaema kaitsmise püha.

7 Midrusk - õigeusukiriku kalendri suurmärter Dmitri Solunski surma mälestuspäev e vanemate laupäev (tähistatakse laupäeval enne 26. oktoobrit).

8 Kaasani maarjapäev e kasansk - Kaasani Jumalaema ikooni päev, tähistab Moskva vabastamist 1612 . aastal.

9 Rakvere raibe - harilik tõlkjas, Põhja- ja Lääne-Eestis tavaline umbrohutaim.

${ }^{10}$ Vissenja - õigeusukalendris ristiülendamise püha (püha risti päev).

${ }^{11}$ Nuudipäeva on Virumaal tähistatud 7. jaanuaril. Taani hertsog Knudi surma-aasta on 1131.

\section{Kirjandus}

Eesti rahvakalender I-VIII. I: 1971 (koost Selma Lätt); II-VIII: 1983-1995 (koost Mall Hiiemäe). Eesti Kirjandusmuuseum. Tallinn: Eesti Raamat.

Moora, Aliise 1964. Peipsimaa etnilisest ajaloost. Ajaloolis-etnograafiline uurimus EestiVene suhetest. Eesti NSV Teaduste Akadeemia Ajaloo Instituut. Tallinn: Eesti Riiklik Kirjastus.

Moora, Aliise 1991. Eesti talurahva vanem toit II. Joogid, leib ja leivakõrvane. Eesti Teaduste Akadeemia Ajaloo Instituut. Tallinn: Valgus.

Põldmäe, Rudolf 1940. Rootsi aja kajastus Eesti rahvamälestustes. Äratrükk Eesti Ajaloo III köitest [Eesti ajalugu III. Tartu: Eesti Kirjanduse Selts]. Tartu: Eesti Rahvaluule Arhiiv.

Tampere, Herbert 1965. Kirde-Eesti rahvakalendri iseärasusi I. (Kommentaare J. Truusmanni üleskirjutistele Iisakust 1886. a.) Moora, Harri \& Jaanits, Lembit (toim). Slaavi-läänemeresoome suhete ajaloost. Artiklite kogumik. Eesti NSV Teaduste Akadeemia Ajaloo Instituut, Keele ja Kirjanduse Instituut, Fr. R. Kreutzwaldi nim Kirjandusmuuseum. Tallinn: Eesti Raamat, lk 205-262. 
Truusmann, Juri 1895 = Trusman, Iurii. Isakskie poluvertsy v Estliandskoi gubernii II. Revel: Estliandskii gubernskii statisticheskii komitet.

Mall Hiiemäe - Eesti Kirjandusmuuseumi Eesti Rahvaluule Arhiivi vanemteadur. mall@folklore.ee

\title{
Summary
}

\section{Calendrical rituals in Virumaa and their regional peculiarities}

\author{
Mall Hiiemäe
}

Keywords: confessional belonging, cultural relations, functional changes, integration, magic, sources of livelihood, Virumaa

The article gives an overview of calendrical rituals in Virumaa region, Estonia, mainly on the basis of customs descriptions preserved in the folklore archives of the Estonian Literary Museum since the last decades of the 19th century. Calendrical themes are complemented by proverbs, narratives about working prohibitions, etc. The influence of ancient Scandinavian agriculture that has persisted in northern Estonia for centuries, shows signs of weakening in the eastern part of Virumaa; in general, emphasis is laid on nature observations, as well as weather and crop-related omens in connection to calendrical holidays. The most important ritual foods are pork and mutton, barley and rye, as well as dairy products.

The northern coast rituals reveal common features with Finnish calendrical traditions; there are also some common holidays unknown in the inland. Indoor jobs were prohibited in the period from All Saints' Day (November 1) to Martinmas (November 10); in this period preferable activities were riddle-guessing and story-telling, not to inflict harm on cattle. St Stephen's Day (December 26) was a public holiday related to horses; on this day men rode on horseback to other households to drink beer.

In the south-eastern part of Virumaa County there is the historic indigenous Votic area, with additional Russian population. This area is influenced by Orthodox calendrical traditions. The celebration of St George's Day (April 23) - the day when cattle were first let into the open - adopted features of an Eastern Slavic women's feast. The souls of the deceased were treated at homes according to the Orthodox calendar - on Parents' Saturday; in other regions of Estonia food was left for ancestors' souls in the autumn, during a longer period.

Mall Hiiemäe is Senior Research Fellow at the Folklore Archives of the Estonian Literary Museum.

mall@folklore.ee 